\title{
Contribution of Captopril Thiol Group to the Prevention of Spontaneous Hypertension
}

\author{
O. PECHÁŇOVÁ ${ }^{1,2}$ \\ ${ }^{1}$ Institute of Normal and Pathological Physiology and Centre of Excellence for Cardiovascular \\ Research, Slovak Academy of Sciences, Bratislava, Slovak Republic, ${ }^{2}$ CRC and Institute of \\ Physiology, AS CR, Prague, Czech Republic
}

Received July 4, 2007

Accepted August 28, 2007

On-line available September 5, 2007

\begin{abstract}
Summary
We aimed to compare the effect of angiotensin converting enzyme (ACE) inhibitors captopril (containing thiol group) and enalapril (without thiol group) on the development of spontaneous hypertension and to analyze mechanisms of their actions, particularly effects on oxidative stress and NO production. Six-week-old SHR were divided into three groups: control, group receiving captopril $(50 \mathrm{mg} / \mathrm{kg} /$ day $)$ or enalapril $(50 \mathrm{mg} / \mathrm{kg} /$ day $)$ for 6 weeks. At the end of experiment, systolic blood pressure (SBP) increased by $41 \%$ in controls. Both captopril and enalapril prevented blood pressure increase, however, SBP in the captopril group $(121 \pm 5 \mathrm{mmHg})$ was significantly lower than that in the enalapril group $(140 \pm 5 \mathrm{mmHg})$. Concentration of conjugated dienes in the aorta was significantly lower in the captopril group compared to the enalapril group. Captopril and enalapril increased NO synthase activity in the heart and aorta to the similar level. Neither captopril nor enalapril was, however, able to increase the expression of eNOS. Both ACE inhibitors increased the level of cGMP. However, cGMP level was significantly higher in the aorta of captopril group. We conclude that captopril, beside inhibition of ACE, prevented hypertension by increasing NO synthase activity and by simultaneous decrease of oxidative stress which resulted in increase of cGMP concentration.
\end{abstract}

\section{Key words}

Spontaneous hypertension $\bullet$ Captopril $\bullet$ Enalapril $\bullet$ Nitric oxide synthase $\bullet$ Thiols $\bullet$ Reactive oxygen species

\section{Introduction}

Angiotensin converting enzyme (ACE) inhibitors are well established drugs in the treatment of hypertension (Williams 1988, Šimko and Šimko 1999, 2000) and protection of the cardiovascular system during congestive heart failure (Šimko 2002, Šimko et al. 2003). Although the pharmacological mechanisms of ACE inhibitors are not fully understood, various studies suggest that these agents may, except inhibition of angiotensin II production, stimulate synthesis of prostaglandins and bradykinin, inhibit production of superoxides, scavenge free radicals, and increase expression of endothelial nitric oxide synthase (eNOS), (Mak et al. 1990, Pecháňová et al. 1997, 2006, Kojšová et al. 2006). Moreover, captopril and enalapril were shown to have direct effects on pathological voltageoperated calcium channel in cardiac myocytes (Wang et al. 1996). 
Captopril, in contrast to enalapril, is the ACE inhibitor involving thiol group, which might participate in formation of thiols and therefore it may have stronger antioxidant effect than other ACE inhibitors. Nevertheless, there are concerns with respect to the intensity of antioxidant effects of thiol-group-containing and non-thiol ACE inhibitors (Bartosz et al. 1997, Šimko et al. 2002a,b). Clearfield et al. (1994) documented that captopril and enalapril were approximately equally active in the prevention of LDL oxidation. Both these ACE inhibitors were shown to increase similarly the activity of superoxide dismutase and glutathione peroxidase in the liver (de Cavanagh et al. 1995) as well as $\mathrm{Na}^{+} / \mathrm{K}^{+}$-ATPase and $\mathrm{Ca}^{2+}$-ATPase activities in erythrocytes (Golik et al. 1996). However, Temel and Akyuz (2007) reported that captopril had an inhibitory effect on red cell plasma membrane $\mathrm{Na}^{+} / \mathrm{K}^{+}$-ATPase activity. Aznaouridis et al. (2007) showed that acute inhibition of renin-angiotensin system with quinapril may be more beneficial in terms of arterial function and central hemodynamics compared to captopril. On the other hand, only captopril, but not enalapril, improved the endothelium-dependent and -independent relaxation responses in the isolated rat aorta of obese Zucker rats (Duarte et al. 1999). Analogically, while collagen-induced platelet aggregation was significantly reduced by captopril, no change was seen with enalapril (Skowasch et al. 2006). Moreover, captopril in contrast to non-thiol group ACE inhibitors was able to protect the heart against arrhythmias induced by ischemia/reperfusion (van Gilst et al. 1986).

The aim of this study was to compare the effect of captopril and enalapril on the development of hypertension in spontaneously hypertensive rats (SHR) and to analyze mechanisms of their actions, particularly effects on oxidative stress, NO synthase activity, eNOS protein expression, and cGMP level in the heart and aorta.

\section{Methods}

\section{Chemicals and drugs}

All the chemicals used were purchased from Sigma Chemicals Co. (Germany) except of those defined in the text.

\section{Animals and treatment}

All procedures and experimental protocols were approved by the Ethical Committee of the Institute of Normal and Pathological Physiology SAS, and conform to the European Convention on Animal Protection and Guidelines on Research Animal Use.

Young 6-week-old male spontaneously hypertensive rats (SHR) were randomly divided into water drinking control group and groups receiving captopril or enalapril in the dose of $50 \mathrm{mg} / \mathrm{kg} /$ day in tap water for 6 weeks ( $n=7$ in each group). All animals were housed in the room with a stable temperature of $23 \pm 1{ }^{\circ} \mathrm{C}$ and fed a regular pellet diet ad libitum. Daily water consumption was estimated individually for every animal one week before the experiment. During the experiment, drinking fluid consumption was controlled and adjusted, if necessary. Systolic blood pressure (SBP) was measured by non-invasive tail-cuff plethysmography every week. After 6 weeks of treatment, the animals were sacrificed and body weight (BW) and heart weight (HW) were determined. The HW/BW was calculated. Concentration of conjugated dienes (CD, the marker of membrane oxidative damage), total NO synthase activity, expression of eNOS protein, and cGMP level were determined in the heart and aorta.

\section{Conjugated diene concentrations}

The concentration of CD was measured in lipid extracts of the heart and aorta homogenates according to Kogure et al. (1982). Briefly, after chloroform evaporation under the inert atmosphere and addition of cyclohexane, $\mathrm{CD}$ concentration was determined spectrophotometrically $(\lambda=233 \mathrm{~nm}$, Bio-Rad, GBC 911A).

\section{Total NO synthase activity}

Total NO synthase activity was determined in crude homogenates of the heart and aorta by measuring the formation of $\mathrm{L}-\left[{ }^{3} \mathrm{H}\right]$ citrulline from $\mathrm{L}-\left[{ }^{3} \mathrm{H}\right]$ arginine (Amersham, UK) as previously described by Bredt and Snyder (1990) with minor modifications (Pecháňová et al. 1997).

\section{Western blot analysis of eNOS}

Samples of the heart and aorta (40 $\mathrm{mg}$ of wet tissue) were homogenized in $25 \mathrm{mmol} / \mathrm{l}$ Tris- $\mathrm{HCl}, \mathrm{pH}$ 7.4, containing $5 \mathrm{mmol} / \mathrm{l}$ EDTA, $50 \mathrm{mmol} / \mathrm{l} \mathrm{NaCl}, 1$ $\mu \mathrm{mol} / 1$ leupeptin, $0.3 \mu \mathrm{mol} / 1$ aprotinin, $0.1 \mathrm{mmol} / 1$ PMSF, $1 \mathrm{mmol} / 1$ pepstatin and $1 \%$ SDS. After the centrifugation (15000 x g, $20 \mathrm{~min}$, twice) supernatants were subjected to SDS-PAGE using $10 \%$ gels. 
Table 1. Body weight (BW) and relative heart weight (HW/BW) in control SHR and SHR treated with captopril and enalapril for 6 weeks.

\begin{tabular}{llll}
\hline & SHR controls & SHR + captopril & SHR + enalapril \\
\hline$n$ & 7 & 7 & 7 \\
$B W(g)$ & $311.7 \pm 10.2$ & $287.4 \pm 12.9$ & $294.0 \pm 10.6$ \\
$H W / B W(m g / g)$ & $3.25 \pm 0.07$ & $2.36 \pm 0.11^{*}$ & $2.48 \pm 0.10^{*}$ \\
\hline
\end{tabular}

Data are means \pm S.E.M., Significant differences: $* p<0.05$ compared to SHR controls.

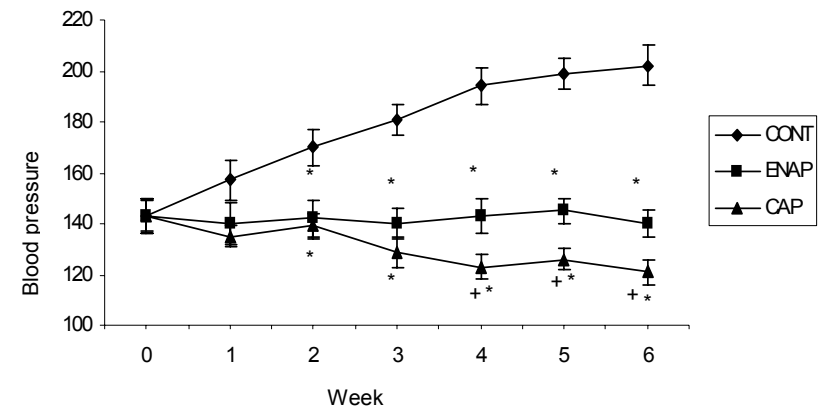

Fig. 1. Effect of 6-week captopril and enalapril treatment on systolic blood pressure of SHR. Control SHR (CONT), enalapril (ENAP), captopril (CAP), significant differences: $* p<0.05$ compared to SHR controls, ${ }^{+} \mathrm{p}<0.05$ compared to enalapril treated SHR.

Following the electro-phoresis, proteins were transferred to nitrocellulose-membranes and were probed with a polyclonal rabbit anti-endothelial NO synthase (Alexis Biochemicals, Germany). Bound antibody was detected using a secondary peroxidase-conjugated anti-rabbit antibody (Alexis Biochemicals, Germany). The bands were visualized using the enhanced chemiluminescence system (ECL, Amersham, UK) and analyzed densitometrically using Photo-Capt V.99 software.

\section{Cyclic GMP concentration}

Cyclic GMP concentration was measured in the heart and aorta using commercial available radioimmunoassay kit (Immunotech, S.A., France) based on the competition between succinylated cGMP of the sample and ${ }^{125}$ I labeled tracer for binding to polyclonal antibody coated onto tubes. Concentration of the cGMP in the sample was calculated from the standard curve and expressed as $\mathrm{pmol} / \mathrm{g}$ tissue.

\section{Statistical Analysis}

The results are expressed as mean \pm SEM. Oneway analysis of variance and Bonferroni test were used for statistical analysis. Values were considered to differ significantly if the probability value was less than 0.05 .
HEART

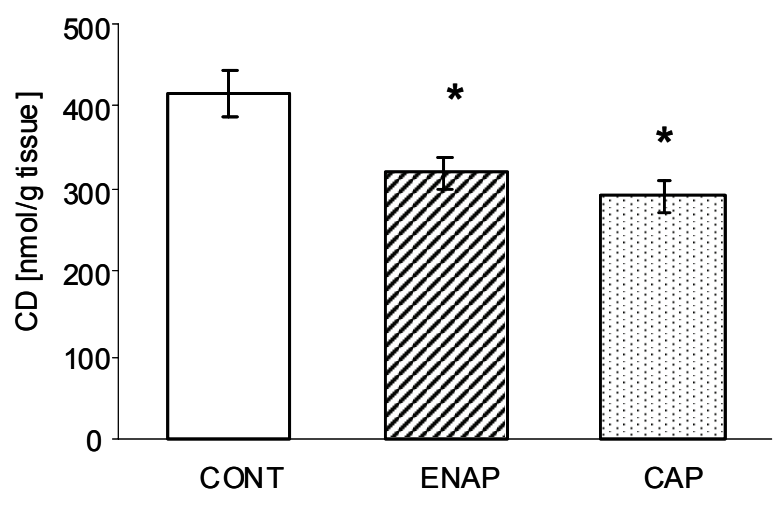

AORTA

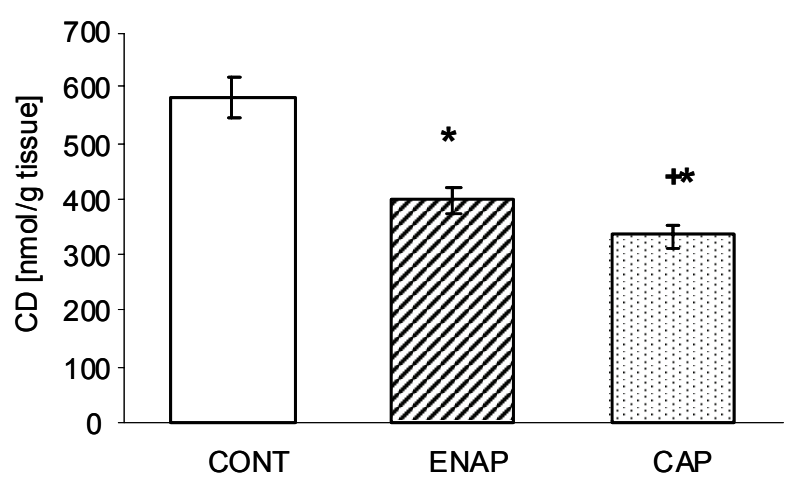

Fig. 2. Effect of 6-week captopril and enalapril treatment on conjugated diene (CD) concentration in the heart and aorta. Control SHR (CONT), enalapril (ENAP), captopril (CAP), significant differences: $* \mathrm{p}<0.05$ compared to SHR controls, + $\mathrm{p}<0.05$ compared to enalapril treated SHR.

\section{Results}

Blood pressure and cardiac hypertrophy

In young SHR, the chronic captopril and enalapril treatment prevented BP increase occurring during the development of spontaneous hypertension. However, at the end of experiment, the systolic blood pressure in the captopril group $(121 \pm 5 \mathrm{~mm} \mathrm{Hg})$ was significantly lower that that in the enalapril group $(140 \pm 5$ 

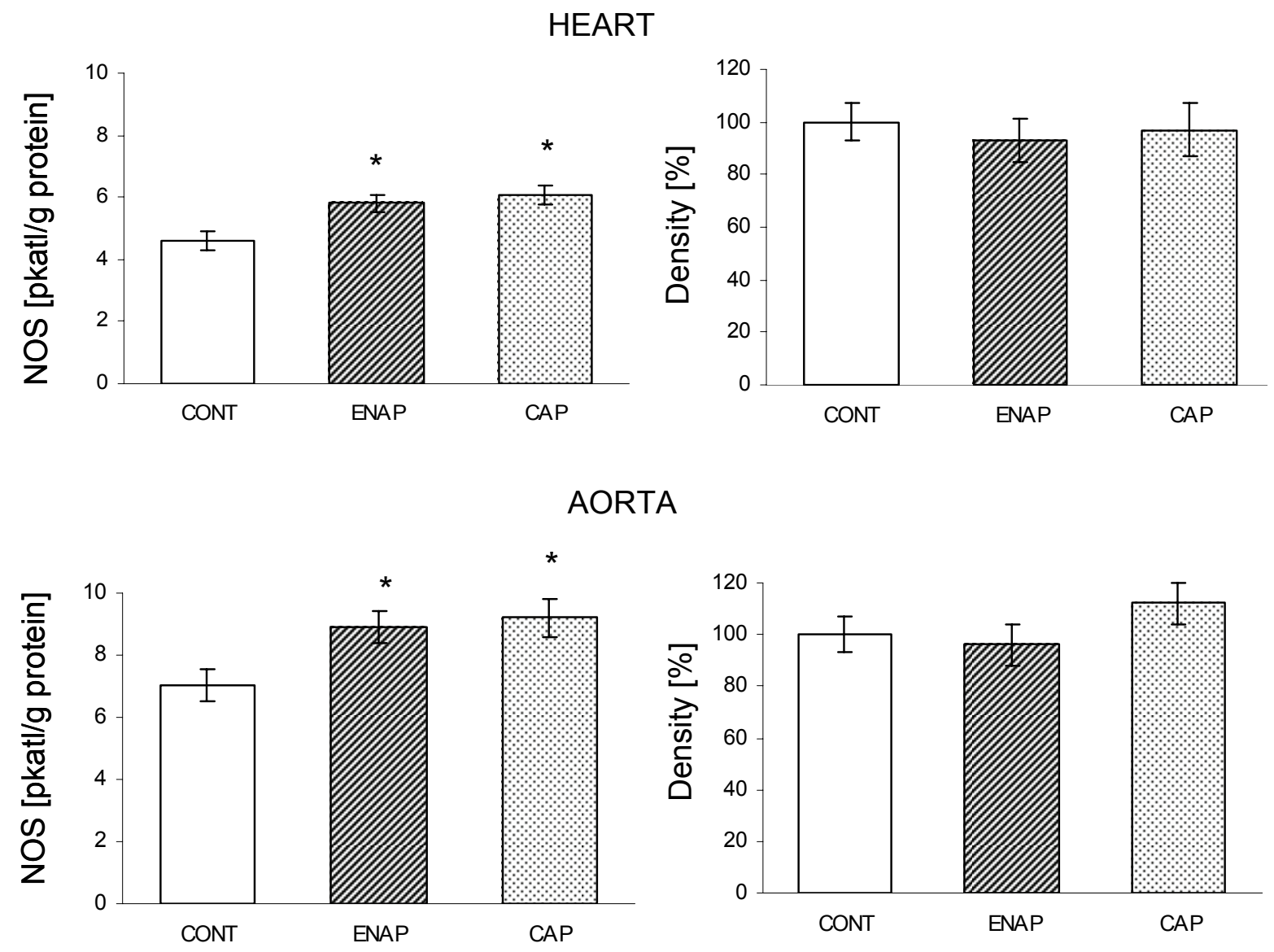

Fig. 3. Effect of 6-week captopril and enalapril treatment on NO synthase activity and eNOS protein expression in the heart and aorta. Control SHR (CONT), enalapril (ENAP), captopril (CAP), significant differences: ${ }^{*} p<0.05$ compared to SHR controls, ${ }^{+} p<0.05$ compared to enalapril treated SHR.

mm Hg), (Fig. 1). Treatment with both ACE inhibitors reduced development of cardiac hypertrophy in young SHR similarly (Table 1).

\section{Conjugated diene concentrations}

Figure 2 indicates that both captopril and enalapril treatment decreased the concentrations of conjugated dienes in the heart and aorta. In the aorta, however, $\mathrm{CD}$ concentration was significantly lower in the captopril group $(335 \pm 19 \mathrm{nmol} / \mathrm{g}$ tissue) than in the enalapril group ( $380 \pm 24 \mathrm{nmol} / \mathrm{g}$ tissue) (Fig. 2).

Total NO synthase activity and eNOS protein expression

Chronic captopril and enalapril treatment increased total NO synthase activity in the heart and aorta to the similar level. Neither captopril nor enalapril was, however, able to increase expression of eNOS protein in the tissues investigated (Fig. 3).

\section{Cyclic GMP concentration}

Figure 4 shows that both captopril and enalapril treatment increased the levels of cGMP in the heart and aorta. In the aorta, however, the level cGMP was significantly higher in the captopril group $(2.94 \pm 0.21$ $\mathrm{nmol} / \mathrm{g}$ tissue) than in the enalapril group $(2.30 \pm 0.15$ nmol/g tissue) (Fig. 4).

\section{Discussion}

This is the first report documenting that chronic captopril treatment is more effective in the prevention of spontaneous hypertension than enalapril treatment. Both ACE inhibitors increased NO synthase activity in the heart and aorta to the similar level. Noteworthy, captopril was able to decrease oxidative stress and to increase cGMP level in the aorta more efficiently than enalapril. Thus, we hypothesize that captopril thiol group may contribute to the beneficial effect of captopril in the prevention of hypertension.

Both ACE inhibitors decreased oxidative damage measured as $\mathrm{CD}$ concentration in the heart and aorta. While similar effect of both drugs was detected in the heart, captopril was more effective than enalapril in 
HEART

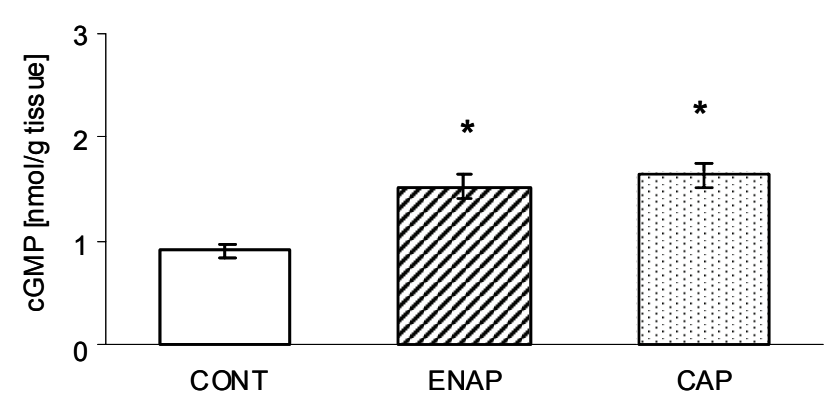

AORTA

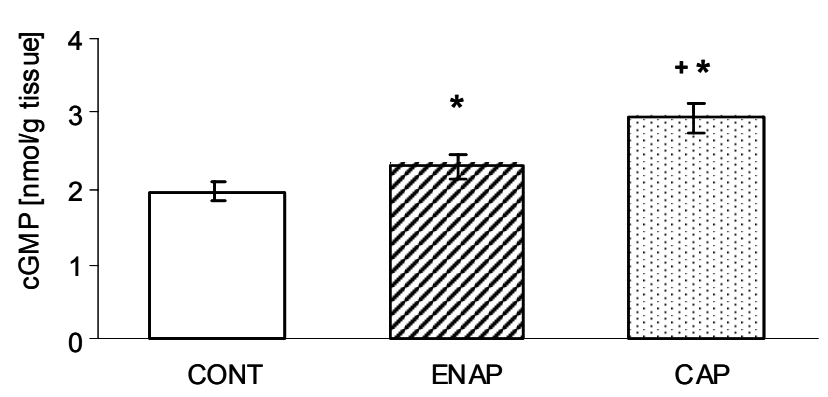

Fig. 4. Effect of 6-week captopril and enalapril treatment on cGMP concentration in the heart and aorta. Control SHR (CONT), enalapril (ENAP), captopril (CAP), significant differences: $* p<0.05$ compared to SHR controls, $+p<0.05$ compared to enalapril treated SHR.

the aorta. It is evident from Figure 2 that in spontaneously hypertensive rats $\mathrm{CD}$ concentration was higher in the aorta than in the heart. Supposedly, the active $\mathrm{NAD}(\mathrm{P}) \mathrm{H}$ oxidase in the endothelial and smooth muscle cells of the aorta (Zalba et al. 2001, Touyz and Schiffrin 2004) contributes to this difference. ACE inhibitors, concomitantly with decreasing angiotensin II production, were shown to inhibit $\mathrm{NAD}(\mathrm{P}) \mathrm{H}$ oxidase activity (Touyz and Schiffrin 2004). Our experiment demonstrated that these two ACE inhibitors are also potent activators of NO synthase. Nevertheless, neither captopril nor enalapril was able to increase expression of eNOS protein in the tissues investigated. Thus, other mechanisms like stabilization of dimeric form of NO synthase by reducing ROS are suggested to participate in NO synthase activation. Moreover, the thiol group of captopril may protect $\mathrm{NO}$ from oxidation by scavenging free oxygen radicals (Lahera et al. 1993) and forming nitrosothiols (Myers et al. 1990), both effects could prolong NO half-life and potentiate its effect. Alternatively this protective effect of captopril could be due to the augmentation of the activity of NO synthase and cGMP cyclase which are thiol-dependent (Ignarro et al. 1981). All the above activities are more expressed within vessels than heart, thus captopril may be more effective in the aorta.

In our experiment, treatment with both $\mathrm{ACE}$ inhibitors reduced development of cardiac hypertrophy in young SHR to the similar level. Probably, the blood pressure difference between SHR treated with captopril and enalapril (although significant during last three weeks) was too small to produce significant changes in the reduction of cardiac hypertrophy. In agreement with our study, the ACE inhibitors captopril and enalapril reversed similarly the cardiovascular complications (cardiac hypertrophy, proteinuria) in the obese Zucker rat, an animal model of non-insulin-dependent diabetes mellitus (Duarte et al. 1999). On the other hand, only captopril, but not enalapril, improved the impaired endothelium-dependent and independent relaxation responses in the isolated rat aorta of the obese Zucker rat (Duarte et al. 1999). Captopril was also able to increase relaxation responses of femoral artery isolated from L-NAME hypertensive rats (Sládková et al. 2007). Miller et al. (2007) demonstrated that captopril, similarly like $\mathrm{NAD}(\mathrm{P}) \mathrm{H}$ oxidase inhibitor apocynin or superoxide dismutase mimetic tempol, potentiated luminal expansion in collaterals of spontaneously hypertensive rats. However, enalapril did not promote luminal expansion.

In our previous works we have also shown that captopril treatment in the dose $100 \mathrm{mg} / \mathrm{kg} /$ day prevented the increase in blood pressure and left ventricular hypertrophy due to chronic NO synthase inhibition (Pecháñová et al. 1997) and reversed the cardiovascular changes in already developed L-NAME-induced hypertension (Bernátová et al. 1999, 2000). Captoprilinduced lowering of sympathetic tone was suggested to be mainly involved in these effects (Zicha et al. 2006a, Hojná et al. 2007). Chronic treatment of hereditary hypertriglyceridemic rats with captopril besides preserving normal blood pressure also prevented the impairment of vascular relaxation (Šimko et al. 2002a, Török et al. 2002, 2007, Zicha et al. 2006b).

Except the rat models, there is also evidence that ACE inhibitors with thiol group induce sustained reduction of systemic oxidative stress and improve the nitric oxide pathway in patients with essential hypertension (Napoli et al. 2004). It was demonstrated that after 12-week treatment, malondialdehyde levels were significantly reduced by zofenopril (ACE inhibitor 
containing thiol group) but not by enalapril. Similarly, isoprostanes were normalized after zofenopril treatment, whereas enalapril was ineffective (Napoli et al. 2004).

Recently, we also demonstrated that chronic administration of N-acetylcysteine (NAC, antioxidant with thiol group) partially attenuated the blood pressure increase occurring in young spontaneously hypertensive rats. Mechanisms responsible for blood pressure reduction appear to be related to both the decrease of reactive oxygen species level and the increase of $\mathrm{NO}$ production (Pecháňová et al. 2006, 2007). While NAC attenuated the blood pressure increase only partially, captopril treatment was able to keep the blood pressure of young SHR on the level of normotensive rats.

In conclusion, it seems that the simultaneous effects of captopril on ACE inhibition, the decrease of oxidative stress and increase of NO synthase activity with increased concentration of cGMP led to a complete prevention of hypertension in young SHR.

\section{Acknowledgement}

Technical assistance of D. Capíková and Y. Hanáčková is highly appreciated. This work was supported by the research grants VEGA - 2/6148/26, 1/3429/06 and APVV-0586-06.

\section{References}

AZNAOURIDIS KA, STAMATELOPOULOS KS, KARATZIS EN, PROTOGEROU AD, PAPAMICHAEL CM, LEKAKIS JP: Acute effects of renin-angiotensin system blockade on arterial function in hypertensive patients. J Hum Hypertens 21: 654-663, 2007.

BARTOSZ M, KEDZIORA J, BARTOSZ G: Antioxidant and prooxidant properties of captopril and enalapril. Free Radic Biol Med 23: 729-735, 1997.

BERNÁTOVÁ I, PECHÁŇOVÁ O, ŠIMKO F: Effect of captopril in L-NAME-induced hypertension on the rat myocardium, aorta, brain and kidney. Exp Physiol 84: 1095-1105, 1999.

BERNÁTOVÁ I, PECHÁŇOVÁ O, PELOUCH V, ŠIMKO F: Regression of chronic L-NAME-treatment-induced left ventricular hypertrophy: effect of captopril. J Mol Cell Cardiol 32: 177-185. 2000.

BREDT DS, SNYDER SH: Isolation of nitric oxide synthetase, a calmodulin-requiring enzyme. Proc Natl Acad Sci USA 87: 682-685, 1990.

CLEARFIELD MB, LEE N, ARMSTRONG L, DEFAZIO P, KUDCHODKAR BJ, LACKO AG: The effect of captopril on the oxidation of plasma lipoproteins. Pharmacol Toxicol 75: 218-221, 1994.

DE CAVANAGH EM, INSERRA F, FERDER L, ROMANO L, ERCOLE L, FRAGA CG: Superoxide dismutase and glutathione peroxidase activities are increased by enalapril and captopril in mouse liver. FEBS Lett 361: 22-24, 1995.

DUARTE J, MARTINEZ A, BERMEJO A, VERA B, GAMEZ MJ, CABO P, ZARZUELO A. Cardiovascular effects of captopril and enalapril in obese Zucker rats. Eur J Pharmacol 365: 225-232, 1999.

GOLIK A, WEISSGARTEN J, EVANS S, COHEN M, AVERBUKH Z, ZAIDENSTEIN R, COTARIU S, MODAI D: Erythrocyte $\mathrm{Na}^{+}, \mathrm{K}^{+}$and $\mathrm{Ca}^{2+}, \mathrm{Mg}^{2+}$-ATPase activities in hypertensives on angiotensin-converting enzyme inhibitors. Clin Biochem 29: 249-254, 1996.

HOJNÁ S, KADLECOVÁ M, DOBEŠOVÁ Z, VALOUŠKOVÁ V, ZICHA J, KUNEŠ J: The participation of brain NO synthase in blood pressure control of adult spontaneously hypertensive rats. Mol Cell Biochem 297: 21-29, 2007.

IGNARRO LJ, LIPPTON H, EDWARDS JC, BARICOS WH, HYMAN AL, KADOWITZ PJ, GRUETTER CA: Mechanism of vascular smooth muscle relaxation by organic nitrates, nitrites, nitroprusside and nitric oxide: evidence for the involvement of S-nitrosothiols as active intermediates. J Pharmacol Exp Ther 218: 739-749, 1981.

KOGURE K, WATSON R, BUSTO R, ABE K: Potentiation of lipid peroxides by ischemia in rat brain. Neurochem Res 7: 437-453, 1982.

KOJŠOVÁ S, JENDEKOVÁ L, ZICHA J, KUNEŠ J, ANDRIANTSITOHAINA R, PECHÁŇOVÁ O: The effect of different antioxidants on nitric oxide production in hypertensive rats. Physiol Res 55 (Suppl 1): S3-S16, 2006. 
LAHERA V, KHRAIBI AA, ROMERO JC: Sulfhydryl group donors potentiate the hypotensive effect of acetylcholine in rats. Hypertension 22: 156-160, 1993.

MAK IT, FREEDMAN AM, DICKENS BF, WEGLICKI WB: Protective effects of sulfhydryl-containing angiotensin converting enzyme inhibitors against free radical injury in endothelial cells. Biochem Pharmacol 40: 2169$2175,1990$.

MILLER SJ, NORTON LE, MURPHY MP, DALSING MC, UNTHANK JL: The role of the renin-angiotensin system and oxidative stress in spontaneously hypertensive rat mesenteric collateral growth impairment. Am J Physiol 292: $\mathrm{H} 2523-\mathrm{H} 2531,2007$.

MYERS PR, MINOR RL JR, GUERRA R JR, BATES JN, HARRISON DG: Vasorelaxant properties of the endothelium-derived relaxing factor more closely resemble S-nitrosocysteine than nitric oxide. Nature $\mathbf{3 4 5}$ : 161-163, 1990.

NAPOLI C, SICA V, DE NIGRIS F, PIGNALOSA O, CONDORELLI M, IGNARRO LJ, LIGUORI A. Sulfhydryl angiotensin-converting enzyme inhibition induces sustained reduction of systemic oxidative stress and improves the nitric oxide pathway in patients with essential hypertension. Am Heart $J$ 148: e5, 2004.

PECHÁŇOVÁ O, BERNÁTOVÁ I, PELOUCH V, ŠIMKO F: Protein remodelling of the heart in NO-deficient hypertension: the effect of captopril. J Mol Cell Cardiol 29: 3365-3374, 1997.

PECHÁŇOVÁ O, MATUŠKOVÁ J, CAPÍKOVÁ D, JENDEKOVÁ L, PAULIS L, ŠIMKO F: Effect of spironolactone and captopril on nitric oxide and S-nitrosothiol formation in kidney of L-NAME-treated rats. Kidney Int 70: 170-176, 2006

PECHÁŇOVÁ O, ZICHA J, PAULIS L, ZENEBE W, DOBEŠOVÁ Z, KOJŠOVA S, JENDEKOVÁ L, SLÁDKOVÁ M, DOVINOVÁ I, ŠIMKO F, KUNEŠ J: The effect of N-acetylcysteine and melatonin in adult spontaneously hypertensive rats with established hypertension. Eur J Pharmacol 561: 129-136, 2007.

ŠIMKO F: Physiologic and pathologic myocardial hypertrophy - physiologic and pathologic regression of hypertrophy? Med Hypotheses 58: 11-14, 2002.

ŠIMKO F, ŠIMKO J: Heart failure and angiotensin converting enzyme inhibition: problems and perspectives. Physiol Res 48: 1-8, 1999.

ŠIMKO F, ŠIMKO J: The potential role of nitric oxide in the hypertrophic growth of the left ventricle. Physiol Res 49: 37-46, 2000.

ŠIMKO F, LUPTÁK I, MATUŠKOVÁ J, BABÁL P, PECHÁŇOVÁ O, BERNÁTOVÁ I, HULÍN I: Heart remodeling in the hereditary hypertriglyceridemic (hHTG) rat: effect of captopril and nitric oxide deficiency. Ann NY Acad Sci 967: 454-462, 2002a.

ŠIMKO F, ŠIMKOVÁ M, KOVACS L: The ACE inhibitor, captopril, in the light of new clinical studies. Ceska Slov Farm 51: 63-67, 2002b

ŠIMKO F, ŠIMKO J, FÁBRYOVÁ M: ACE-inhibition and angiotensin II receptor blockers in chronic heart failure: pathophysiological consideration of the unresolved battle. Cardiovasc Drugs Ther 17: 287-290, 2003.

SKOWASCH D, VIKTOR A, SCHNEIDER-SCHMITT M, LUDERITZ B, NICKENIG G, BAURIEDEL G: Differential antiplatelet effects of angiotensin converting enzyme inhibitors: comparison of ex vivo platelet aggregation in cardiovascular patients with ramipril, captopril and enalapril. Clin Res Cardiol 95: 212-216, 2006.

SLÁDKOVÁ M, KOJŠOVÁ S, JENDEKOVÁ L, PECHÁŇOVÁ O: Chronic and acute effects of different antihypertensive drugs on femoral artery relaxation of L-NAME hypertensive rats. Physiol Res $\mathbf{5 6}$ (Suppl 2): S85-S91, 2007.

TEMEL HE, AKYUZ F: The effects of captopril and losartan on erythrocyte membrane $\mathrm{Na}^{+} / \mathrm{K}^{+}$-ATPase activity in experimental diabetes mellitus. $J$ Enzyme Inhib Med Chem 22: 213-217, 2007.

TÖRÖK J, BABÁL P, MATUŠKOVÁ J, LUPTÁK I, KLIMEŠ I, ŠIMKO F: Impaired endothelial function of thoracic aorta in hereditary hypertriglyceridemic rats. Ann N Y Acad Sci 967: 469-475, 2002.

TÖRÖK J, MATUŠKOVÁ J, PECHÁŇOVÁ O, KRAJČIROVIČOVÁ K, ŠIMKO F: Simvastatin, but not L-arginine, improves endothelial function of aorta in hereditary hypertriglyceridemic rats. Physiol Res $\mathbf{5 6}$ (Suppl 2): S33S40, 2007. 
TOUYZ RM, SCHIFFRIN EL: Reactive oxygen species in vascular biology: implications in hypertension. Histochem Cell Biol 4: 339-352, 2004.

VAN GILST WH, DE GRAEFF PA, WESSELING H, DE LANGEN CDJ: Reduction of reperfusion arrhythmias in the ischemic isolated rat heart by angiotensin converting enzyme inhibitors: a comparison of captopril, enalapril, and HOE 498. J Cardiovasc Pharmacol 8: 722-728, 1986.

WANG J, ZHANG L, QI JH, ZHANG PJ, WEI PJ, GU PK, JIN ZJ. Effects of captopril and enalaprilat on intracellular $\mathrm{Ca} 2+$ content in isolated cardiomyocytes from rats. Zhongguo Yao Li Xue Bao 17: 233-235, 1996.

WILLIAMS GH: Converting-enzyme inhibitors in the treatment of hypertension. $N$ Engl J Med 319: 1517-1525, 1988.

ZALBA G, BEAUMONT FJ, SAN JOSE G, FORTUNO A, FORTUNO AM, DIEZ J: Is the balance between nitric oxide and superoxide altered in spontaneously hypertensive rats with endothelial dysfunction? Nephrol Dial Transplant 16 (Suppl 1): 2-5, 2001.

ZICHA J, DOBEŠOVÁ Z, KUNEŠ J: Antihypertensive mechanisms of chronic captopril or N-acetylcysteine treatment in L-NAME hypertensive rats. Hypertens Res 29: 1021-1027, $2006 \mathrm{a}$.

ZICHA J, PECHÁŇOVÁ O, ČAČÁNYIOVÁ S, CEBOVÁ M, KRISTEK F, TÖRÖK J, ŠIMKO F, DOBEŠOVÁ Z, KUNEŠ J: Hereditary hypertriglyceridemic rat: a suitable model of cardiovascular disease and metabolic syndrome? Physiol Res 55 (Suppl 1): S49-63, $2006 \mathrm{~b}$.

\section{Corresponding author}

Ol'ga Pecháňová, Institute of Normal and Pathological Physiology, Slovak Academy of Sciences, Sienkiewiczova 1, 81371 Bratislava, Slovak Republic, Fax: +421-2-52968516. E-mail: olga.pechanova@savba.sk 